\title{
De-segmenting Research in Entrepreneurial Finance
}

\author{
Douglas J. Cumming \\ dcumming@schulich.yorku.ca \\ Schulich School of Business \\ York University \\ 4700 Keele Street, Toronto, Ontario, Canada, M3J 1 P3 \\ Tel.: +1-647-280-3410 \\ Silvio Vismara \\ silvio.vismara@unibg.it \\ Department of Economics and Technology Management \\ University of Bergamo \\ Viale Marconi, 5 - 24044 Dalmine (BG), Italy \\ Tel.: +39-035-205-2352
}

This draft: February 20, 2016

\begin{abstract}
.
Entrepreneurial finance literature is largely segmented. Different streams of the academic literature between entrepreneurship and finance have become segmented for reasons of theoretical tractability and data availability. In this paper, we discuss the origins and the effects of segmentation by source of financing, by data source, by field, and by country under investigation. We provide a number of examples, mainly from studies on Venture Capital, Initial Public Offerings, and Crowdfunding. We conclude with future research directions, with the hope to help de-segmenting research on entrepreneurial finance.
\end{abstract}

\section{Keywords:}

Entrepreneurial Finance; Crowdfunding; VCs; IPOs.

We would like to thank Cristiano Bellavitis and Tom Vanacker for his very helpful comments. We would also like to thank participants at the Workshop "Economics of Entrepreneurship and Innovation" in Trier, Germany. 


\section{Introduction}

The increasing importance of entrepreneurial firms as 'engines' of economic development has led to enhanced interest in these firms among policymakers, regulators and academics. Agency problems, information asymmetries and lack of internal cash flows or collaterals make it difficult for entrepreneurial firms to raise funds. As a result, questions about the role and impact of legal and market infrastructures on the nature and availability of capital for these firms have been central to research in finance and entrepreneurship for some time. Recently, the understanding of how these firms' financing decisions evolve has attracted considerable interest. However, while some topics, such as venture capital (VC) has received a lot of attention, others have been left behind. For instance, the literature has only skimmed the surface in terms of studying some financial bootstrapping for entrepreneurial firms. Moreover, the emergence of new trends in entrepreneurial finance, such as crowdfunding, has led to new avenues for research grounded in both financial economics and entrepreneurship. Coherently, a few special issues have and are going to be dedicated to the topic, including those on the way by Block, Colombo, Cumming and Vismara for Small Business Economics: an Entrepreneurship Journal, by Bruton, Khavul, Siegel, and Wright for Entrepreneurship: Theory \& Practice, and by Block, Cumming and Vismara for the Journal of Industrial and Business Economics (Economia e Politica Industriale).

In their call for papers for this special issue, Cristiano Bellavitis, Igor Filatotchev, Sam Kamuriwo, and Tom Vanacker argue that "the entrepreneurial finance literature is largely segmented". In this paper, we discuss how entrepreneurial finance literature is segmented (1) by source of financing (e.g. public vs private equity, Initial Public Offerings vs equity-based crowdfunding), (2) by data source (e.g., from investors, entrepreneurs), (3) by field of investigation (e.g. Finance, Entrepreneurship, Law), and (4) by country under investigation (e.g. US-based studies are typically appreciated in finance journals). The next four Sections are 
dedicated to the discussion of the possible origins and effects of each of these four types of segmentation. We then conclude offering future research directions, with the hope to help desegmenting research on entrepreneurial finance.

\section{Literature segmented by source of financing}

Segmented studies treat the source of capital as the only source of financing received by the entrepreneurial firm (Cosh et al. 2009). For example, most VC studies do not acknowledge that the firm may have received money from other sources of capital. In general, entrepreneurs raise financing from multiple sources, and it is valuable to study how these sources interact (Hanssens et al. 2015). In this section, we identify some new trends and new financial instruments that might be worth investigating. To do so, we start from the taxonomy of financing means available to entrepreneurial firms. Table 1 graphically summarizes such means of financing.

The first broad distinction is between equity and debt financing. Many discussions have revolved around the unsuitability of debt for early-stage financing (Stiglitz and Weiss, 1981). This is mainly due to the fact that debt holders bear the downside risk, but do not share the upside of successful innovation (Berger and Udell, 1998). In the absence of sufficient internally generated cash flows, internal equity is often not a viable option for entrepreneurial firms. Our discussion in this Section will be therefore focused on raising equity capital. We are, anyway, aware that this represents a bias in the entrepreneurial finance literature. There is indeed evidence that even early stage entrepreneurial firms rely extensively on bank debt (e.g., Cassar, 2004; Cassia and Vismara, 2009b; Robb and Robinson, 2014; Hanssens et al., 2016).

Moreover, there are new forms of debt capital for entrepreneurial firms that are quickly developing, such as mini-bonds. It is not currently clear whether the trading of mini-bonds will take place mostly on traditional regulated markets (e.g. ExtraMOT in Italy) or new 
crowdfunding platforms (e.g. Crowdcube in the United Kingdom). It is also not clear what will happen when/if interest rates increase, making traditional bank lending less appealing than it currently is. Other forms of debt capital for entrepreneurial firms include credit-based crowdfunding or peer-to-peer $(\mathrm{P} 2 \mathrm{P})$ business lending. These are debt-based transactions between individuals and existing businesses (mostly small firms), with many individual lenders contributing to one loan. The study of these financing mechanisms offers promising ways to contribute to entrepreneurial finance literature.

Crowdfunding involves raising funds from a large pool of backers (crowd) collected online by means of a web platform. These platforms will need to cope with collective-action problems, as crowd-investors have neither the ability nor the incentive, due to small investment sizes, to devote substantial resources to due diligence (Vismara 2016a; which is in contrast to the extensive due diligence of VC and PE funds (Cumming and Zambelli, 2016)). How to protect investors in crowdfunding is a challenging topic to address. Many of the traditional research questions in entrepreneurship and finance could be reexamined in the crowdfunding context, with both lending and equity-based platforms. For instance, scholars could exploit this context to derive new insights or study questions that are difficult to address in other contexts. Some recent work indicates that crowdfunding platforms that undertake more extensive due diligence have on average better performing entrepreneurial campaigns (Cumming and Zhang, 2016). There are two distinctions in the realm of external equity: namely, private vs. public equity and intermediated vs. disintermediated finance. The first categorization is clear and has been broadly investigated. We believe that the second distinction has gained new momentum, particularly in terms of disintermediated finance, which takes the form of business angels and crowdfunding platforms. ${ }^{1}$ Disintermediated finance allows entrepreneurial firms to raise funds

\footnotetext{
${ }^{1}$ The impact of financial intermediation has been a subject of considerable attention in the literature. In perfect markets, financial intermediaries would not be need, as individuals and firms can transact seamlessly with each other. In the real world, the role of intermediaries is to overcome transaction cost
} 
directly from individual investors off line (business angels) or on line from Internet users (crowdfunding) and seems suitable for financing entrepreneurial firms in their early stages, when firms are not yet attractive for venture capitalists and are not ready for an initial public offering (IPO).

Little is known about the effectiveness of disintermediated entrepreneurial finance in solving the financial constraints of entrepreneurial firms. By easing the manner in which demand for capital meets supply, the development of crowdfunding platforms is expected to improve the efficiency of financial markets (Agrawal et al. 2015). However, the Internet has long presented the promise of entrepreneurial finance disintermediation, if not democratization. For example, in the 1990s, online auction IPOs were viewed as an alternative to the traditional book-building method of IPO underwriting and an efficient market mechanism to lower costs of going public (Ritter 2013). Unfortunately, the expectations of online auction IPOs were never realized. Only one investment bank, W.R. Hambrecht, has developed a platform for online public offerings, and only 20 American companies, the most notable being Google, have gone public with online auctions (see Jay Ritter's IPOs Updated Statistics). The last auction IPO was held on May 25, 2007 (Clean Energy Fuels).

Regarding the VC industry, the recent financial crisis has increased the difficulty for entrepreneurial firms to raise seed and early-stage finance, as traditional venture capitalists have become more risk adverse and focused on later-stage investments (Block and Sandner 2009). Many OECD countries have begun implementing policy interventions (Wilson and Silva 2013), such as using governmental venture capital (GVC) funds as a mechanism to address relevant socioeconomic challenges. Besides addressing the financial gap problem, it is expected that these funds will be used to pursue investments that will ultimately yield social

and information problems. They may, however, be prone to agency conflicts, that lead them to neglect the interest of their capital providers. 
payoffs and positive externalities on society as a whole. ${ }^{2}$ However, the effects of GVC at the systemic level (i.e. crowding in vs. crowding out) and firm level (i.e. selection vs. treatment) have not always been positive, as reviewed in Colombo et al. (2016). Furthermore, controversial academic debate has surrounded the rationale and appropriateness of these programs. Assessing the impact of public policy on VC markets seems particularly important in this climate, and some academic work on topic is completely wrong (for details and an explanation, see for example Colombo et al., 2016, and Cumming and Johan, 2013).

\section{--- TAKE IN TABLE 1 HERE ---}

\section{Literature segmented by data source}

We believe that the scarcity of publicly available data on entrepreneurial finance is among the causes of segmentation in the literature. Although some fields of finance research, such as asset pricing, are based on large, publicly available datasets, most entrepreneurial finance papers are instead based on cross-sectional or, more recently, longitudinal datasets developed with data collected for a specific study. The data-collection process is therefore particularly challenging and delicate for entrepreneurial finance research. For instance, research on entrepreneurial motivations is often based on qualitative studies and surveys, whereas papers on valuation use hand-collected data, such as from IPO prospectuses (e.g. Khurshed et al. 2014; Paleari et al. 2014; Vismara et al. 2012) or analysts' equity research reports (e.g. Cassia and Vismara 2009a; Vismara et al. 2015).

More broadly, data often come from different sources, such as investors, entrepreneurs, internet, groups or organizations. A growing number of papers is using data from the website crunchbase (e.g. Cumming et al., 2016). Many studies involve empirical testing using data

\footnotetext{
${ }^{2}$ Minola et al. (2016) study how the objective functions of GVC funds affect their investment screening methods.
} 
from vendors, such as Thompson SDC or VentureOne. Crowdfunding data, publicly available from platforms, are now frequently used (e.g., Ahlers et al. 2015; Vismara 2016b). The availability and easy access to data have surely influenced the recent growth in the number of crowdfunding papers. Of course, many entrepreneurial firms never reach or do not want to reach the public equity stage. Thus, studying only IPOs and crowdfunded firms entails a selection bias.

Occasionally, such as in some bank and VC studies, datasets are merged to study two sources of capital simultaneously. Other times, small samples may be hand collected, such as for studies investigating issues that cannot be addressed using datasets from data vendors. For example, as VC contract details are not available from data vendors, papers might use surveys or actual contracts (e.g., Cumming 2008). Similarly, many papers match IPO data, often hand-collected, with merger and acquisition (M\&A) data, often from datasets such as Thomson Onebanker (e.g. Bonardo et al. 2010; Cattaneo et al. 2015; Meoli et al. 2013). Nowadays, there are a number of communities of traders, analysts or business angels where to collect data or pursue experiments. As an example, Bernstein et al. (2016) use a randomized field experiment involving 4,500 active, early stage investors to study which start-up characteristics are most important to investors in early-stage firms. The experiment took place on AngelList, an online platform that matches investors with start-ups seeking capital. Researchers might also take advantage of information freely available online, that can be downloaded using specific software and macros and integrated in existing datasets. The plethora of research questions that could be answered accessing individual level data is vast.

So far, we mostly discussed research opportunities using data at an investor level, or with regard to financial intermediaries. This is only one side of the story. From the side of the demand for capital, studies based on data gathered from entrepreneurs are typically based on large-scale surveys. The Kauffman Surveys in the US (Robb and Robinson, 2014) or the Center 
for Business Research (CBR) at Cambridge (Cosh et al., 2009) are two widely used examples. What the CBR and Kauffman datasets both show is that VC is rare, and most entrepreneurs use debt finance, which suggests that the focus of research on VC might be disproportionate. However, a recent study that directly compares the impact of $\mathrm{VC}$ and bank finance on firm growth shows a stronger impact of $\mathrm{VC}$ on growth than bank finance, even after controlling for endogeneity of possibly faster growth companies seeking VC (Cole et al., 2016).

Last, data could come from groups or organizations. These often include data from the supply side, such as business angel groups or various VC associations. From a different perspective, most literature on public intervention has focused on demand-side public interventions, such as technology transfer offices, incubators, accelerators, proof-of-concept centers and other initiatives of network development, as well as matchmaking involving prospective entrepreneurs and investors (Audretsch, et al, 2016). Although the diffusion of such types of gap funding schemes has increased in the United States and in Europe over the last decade, we still miss a comprehensive empirical assessment of the nature and output of such programs, as well as policy evaluation exercises adopting rigorous empirical methods. New insights could come from studies using data from technology parks, industry associations, governmental organizations and statistical agencies.

\section{Literature segmented by field of investigation}

Although both topics are at the crossroad between economics and management, finance and entrepreneurship are two distinct research areas. This distinction results in a segmented literature with different specificities in the structure and objectives of papers published in finance vs. entrepreneurship journals. Cumming's (2015) chapter on 'Publishing in Finance versus Entrepreneurship/Management Journals' presents some anecdotes and advice about the 
opportunities and pitfalls that different fields offer to researchers. In this section, we briefly summarize some of the key differences and comment on how to evolve.

Unlike entrepreneurship papers, finance papers typically do not have a verbal theory section. If there is one, this section is generally short and to the point. Similarly to economic but different from management papers, formal mathematical models are sometimes discussed in finance papers, typically preceding an empirical analysis. Finance papers often investigate a phenomenon as fully as possible, without necessarily identifying a clear theoretical contribution. By contrast, entrepreneurship papers prefer to focus on longer verbal theory sections with formal, testable hypotheses. While allowing clear identification of the paper's contribution, this approach can lead to 'salami publishing', in which authors inflate the total number of publications by subdividing published output into numerous thin 'slices' or 'least publishable units' (Martin 2013, 2016). Empirical tests in management papers are often less concerned about the data quality or completeness of robustness checks, as long as the research question is new and interesting. Finance papers, by contrast, are extremely resolute about demonstrating robustness, even when the research question is not terribly new.

Owing to this field segmentation, literature on entrepreneurial finance has evolved through distinct paths, with the same topic often being addressed from multiple perspectives. When different streams of research study the same thing, authors might respond by conveniently ignoring work by other authors, to make their studies look innovative to a segmented readership. Examples of 'rediscoveries' are not rare in entrepreneurial finance. For instance, recent papers on $\mathrm{VC}$ (e.g. exits, investor behavior, etc.) claim to present new findings while merely repeating work done previously by others. This situation results in a large number of separate publications, whereas the research community might be better served if the results were combined into fewer publications. 
Relatedly, there is the problem of 'silos' of citation patterns, whereby finance journals tend to not cite entrepreneurship journals, and sometimes entrepreneurship studies do not acknowledge finance studies. It is clearly easier to claim your paper is new when the reviewers themselves are segmented. Finally, perhaps even more dramatic, segmentation allows for higher possibilities of frauds, e.g. where a single author multiple submit the same paper to a finance journal and an entrepreneurship journal at the same time, or mistakes, not detected in a field, that generate misinformed inferences for public policy, and correlated mistakes with future studies. Critical re-examination of previous results is crucial to our profession and for a 'Darwinian' survival of the fittest applied to theories.

\section{Literature segmented by country}

Thus far, we have mostly focused on new trends in entrepreneurial finance related, directly or indirectly, to technological innovation. For instance, crowdfunding is a new financing opportunity that is available thanks to advancements in information and communication technologies. The concurrent trend of globalization has also affected entrepreneurial finance over the last decade. Globalization is leading to greater awareness of the importance of the international dimension of research. Theories and practices developed in a single institutional setting do not necessarily hold across countries, regions and cultures (Vanacker et al. 2014). Nevertheless, at the moment, international research represents a modest, though growing, part of the empirical research in entrepreneurial finance. A possible problem with single-country studies is that results differ depending on the selected country.

As a first example, almost all papers in VC finance assume that convertible preferred equity is optimal. However, whereas convertibles are the most frequently used equity type in the United States, the opposite is true for every other country in the world, according to data for Canada (Cumming 2005; Cumming and Johan 2008a), Australia (Cumming et al. 2005), Europe 
(Cumming 2008; Cumming and Johan 2008b) and developing countries (Cumming et al. 2010; Lerner and Schoar 2005). Furthermore, many VC-related studies focus on Silicon Valley and the Boston area in the United States. Although these locations are interesting cases, they are also very unique environments. VC funds might work very differently elsewhere.

As a second example, the two stock exchanges in the United States (i.e. NYSE and NASDAQ) represent an integrated underwriting market, with companies that are going public selecting investment banks independently of, and even before, the listing market. For this reason, researchers use a single classification of IPO underwriters in the United States that encompasses stock exchange activities and typically relies on Carter-Manaster ranking to measure their reputation (Carter and Manaster 1990). In contrast, most IPOs in Europe involve local underwriters or 'national champion' banks, such as Mediobanca and Commerz Bank, which operate almost entirely in a single country (Abrahamson et al. 2011). Their reputations are supposedly high in domestic IPO markets, but lower abroad. For instance, the investment bank Evolution Securities is the underwriter that took public more companies on London's Alternative Investment Market (AIM) than any other underwriter in this market, although it rarely operates outside the AIM. In a study of UK or European IPOs, the reputation of such underwriters specialized in single, second-tier markets would appear to be negligible. For this reason, different measures of underwriter reputation, such as those proposed by Migliorati and Vismara (2014), should be used when studying non-US IPOs.

Finance journals have traditionally focused mainly on US or, possibly, UK studies. We still hear well-published finance colleagues recommending our PhD students and junior faculty to use US/UK data. There are, of course, exceptions. Jay Ritter, for instance, welcomes IPO papers from different countries, if they deliver fresh insights (Cumming and Vismara 2016). Although the US/UK bias is hopefully going away, it is puzzling with regards to both research outcomes and research funding. The governments of Canada or Italy, for instance, are not 
subsidizing their universities to understand how entrepreneurship works in the United States. Studying the local context would bring an informational advantage and, ultimately, better and more diversified works. The onus is in 'selling' that context to a broader audience.

Highlighting country specificities that are believed to be the standard for a topic is a contribution that might arise from cross-country study. We hope that a larger number of comparative studies will emerge in entrepreneurial finance, as it is essential to progress accumulating knowledge. Relatedly, we also encourage scholars to attempt to replicate original results in independent datasets and different institutional settings. Entrepreneurial finance studies with cross-border comparisons might draw from other fields of research, including legal (e.g., La Porta et al., 1998), cultural (e.g., Hofstede, 1980), and economic and other institutional analyses. Examples of such cross-country approach in private equity include the book by Cumming and Johan (2013) on venture capital and private equity around the world, as well as in a number of publications empirically based on the VICO dataset of VC investments in Europe (Bertoni et al., 2013a; 2013b; 2015; 2016; Devigne et al., 2013). Similarly, a growing number of papers is taking a comparative approach to investigate the effects of institutional setting on several variables measure at the IPO (e.g., Akyol et al., 2014; Bertoni et al., 2014; Bonardo, Paleari, Vismara, 2011; Levis and Vismara, 2013; Judge et al., 2010; Judge et al., 2014, Zattoni and Judge, 2012).

Last, we highlight that globalization and technological innovation interact in their effect on entrepreneurial finance. The reduction in communications costs due to technological innovation have, for instance, made cross-border investments easier (Chemmanur and Fulghieri, 2014). Thanks to technological innovation, the costs of monitoring investments over long distances is decreasing, delivering new avenues for investing VC cross-board deals and subsequent monitoring activity. Microfinance is also changing rapidly, with a number of crowdfunding platforms dedicated to developing countries. 


\section{Conclusions}

We conclude by proposing research directions that we are likely to pursue more deeply in the future. As we noted above, entrepreneurial finance is arguably more segmented than other fields. We believe that research opportunities will arise from revisiting prior conclusions using new datasets. Following our discussion of four kinds of segmentations, new papers could deliver fresh insights by merging datasets across sources of capital, entrepreneurs/investors, countries, etc. For instance, we still miss comprehensive analyses on the factors that drive the matching between entrepreneurial firms and investors in the new forms of financing. We still do not know to what extent the characteristics of both investors and entrepreneurs are responsible for generating matching in disintermediated entrepreneurial finance markets. This matching may depend on several factors, concerning the venture to be funded, the entrepreneurs' and investors' characteristics, besides other idiosyncratic aspects. In particular, scholars often envisage a positive sorting matching between investors and entrepreneurs, so that the most reputable investors choose the best entrepreneurs. Augmented datasets can help solving these and other research questions.

A second future direction is related to natural experiments. Many studies in entrepreneurial finance, and in corporate finance more generally, suffer from causality problems. Studies that look at unusual events (natural experiments) are potentially better suited to understand causality. Examples are changes in laws or institutional conditions and new markets over time (e.g., bankruptcy laws, crowdfunding rules, bitcoin), changes in airline routes (travel time for VCs to get to entrepreneurs), as well as changes in weather patterns (e.g., snowfall and capital structure). More broadly, we need most rigorous empirical methods for causal inference. A methodologically appropriate approach may require difference-in-differences, regression discontinuity, propensity score matching, Chow tests, instrumental variables, or cluster 
analysis. Further, experimental economics can offer many insights into entrepreneurial and investor behavior. The challenge of controlled experiments is in practice to create environments that folks believe will be applicable to the real world. Examples are the World Bank studies on microfinance (e.g., randomized policy experiments), studies of retail stores (e.g., use of video surveillance) and studies of groups investors and entrepreneurs (e.g., intentionally sending investors differential sets of information on entrepreneurs to understand their responses and investment behavior).

Finally, we conclude with a call for interdisciplinary work to de-segment entrepreneurial finance. We argued above that entrepreneurial finance studies with cross-border comparisons might draw from other fields of research, including legal, cultural, and economic and other institutional analyses. As real-life problems involve multiple dimensions, fundamental research questions require a multidisciplinary skillset. Scholars more equipped with such skills are likely to be more creative due to their ability to draw analogies across fields. Theoretical and methodological approaches in one area can inspire or be applied to another, yielding new insights. This is difficult to achieve and rarely take place, with exceptions often confined to closely related fields, such as finance and accounting. There is indeed a publishing home biases, as discussed in Cumming (2015), and a lack of incentives for multidisciplinary studies. Researchers are instead incentivized to focus on a particular issue in a single discipline as higher education systems tend to reward faculty who publish in a certain set of highly ranked journals (Adler and Harzing, 2009), where status is achieved through specialization (Leahey, 2007). We hope this changes. 


\section{References}

Abrahamson, M., Jenkinson, T., Howard, J., 2011. Why Don't U.S. Issuers Demand European Fees for IPOs?. Journal of Finance, 66, 2055-82.

Adler, N., Harzing, A. W., 2009. When Knowledge Wins: Transcending the sense and nonsense of academic rankings. Academy of Management Learning \& Education, 8(1), 72-95.

Agrawal, A., Catalini, C., and Goldfarb, A., 2015. Crowdfunding: Geography, Social Networks, and the Timing of Investment Decisions. Journal of Economics \& Management Strategy, 24(2), 253-274.

Ahlers G.K.C., Cumming D., Günther C., Schweizer, D., 2015. Signaling in equity crowdfunding. Entrepreneurship: Theory and Practice, 39(4), 955-980.

Akyol A., Cooper T., Meoli M., Vismara S., 2014. Do regulatory changes affect the Underpricing of European IPOs? Journal of Banking and Finance, 45, 43-58.

Audretsch D., Lehmann E., Paleari S., Vismara S., 2016. Entrepreneurial finance and technology transfer. Journal of Technology Transfer, 41(1), 1-9.

Berger, A.N., Udell, G.F., 1998. The economics of small business finance: The roles of private equity and debt markets in the financial growth cycle. Journal of Banking \& Finance, 22 (6-8), 613-673.

Bernstein, S., Korteweg, A., Laws, K., 2016. Attracting Early Stage Investors: Evidence from a Randomized Field Experiment. Journal of Finance. Forthcoming.

Bertoni F., Colombo M. G., Grilli L., 2013a. Venture capital investor type and the growth mode of new technology-based firms. Small Business Economics, 40 (3), 527-552.

Bertoni F., Colombo M. G., Quas A., 2015. The patterns of venture capital investment in Europe. Small Business Economics, 45 (3), 543-560.

Bertoni F., Ferrer M. A., Marti Pellon J. 2013b. The different roles played by venture capital and private equity investors on the investment activity of their portfolio firms. Small Business Economics, 40 (3), 607-633.

Bertoni F., Meoli M., Vismara S., 2014. Board Independence, Ownership Structure, and the Valuation of IPOs in Continental Europe. Corporate Governance: An International Review, 22, 116-131.

Bertoni F., D’Adda D., Grilli L., 2016. Cherry-picking or frog-kissing? A theoretical analysis of how investors select entrepreneurial ventures in thin venture capital markets. Small Business Economics, forthcoming.

Block, J., Sandner, P., 2009. What is the effect of the financial crisis on venture capital financing? Empirical evidence from US internet start-ups. Venture Capital - An International Journal of Entrepreneurial Finance, 11, 295-309.

Bonardo D., Paleari S., Vismara S., 2010. The M\&A dynamics of European Science Based Entrepreneurial Firms. Journal of Technology Transfer, 35 (1), 141-180.

Bonardo D., Paleari S., Vismara S., 2011. Valuing university-based firms: the effects of academic affiliation on IPO performance. Entrepreneurship: Theory and Practice, 35 (4), 755-776.

Carter, R., Manaster, S., 1990. Initial public offerings and underwriter reputation. Journal of Finance, 45, 1990, 1045-67.

Cassia L., Vismara S., 2009a. Valuation accuracy and infinity horizon forecast: Empirical evidence from Europe. Journal of International Financial Management and Accounting, 20 (2), 135-165.

Cassia L., Vismara S., 2009b. Suppliers as fund suppliers: Firms' trade credit and the local level of development of the banking system in Europe. Investment Management and Financial Innovations, 6 (4), 46-58. 
Cattaneo M., Meoli M., Vismara S., 2015. Cross-border M\&As of biotech firms affiliated with internationalized universities. Journal of Technology Transfer, 40, 409-433.

Chemmanur, T.J., Fulghieri, P. 2014. Entrepreneurial finance and innovation: An introduction and agenda for future research. Review of Financial Studies 27 (1), 1-19.

Cole, R., Cumming, D.J., Li, D., 2016. Do banks or VCs spur small firm growth? Journal of International Financial Markets, Institutions and Money, 41(1), 60-72.

Colombo M., Cumming D. J., Vismara S., 2016. Governmental venture capital for innovative young firms. Journal of Technology Transfer, 41(1), 10-24.

Cosh A, Cumming D, Hughes A, 2009. Outside Entrepreneurial Capital. Economic Journal 119, 1494-1533.

Cumming, D.J., 2005. Agency Costs, Institutions, Learning and Taxation in Venture Capital Contracting. Journal of Business Venturing 20, 573-622.

Cumming, D.J., 2008. Contracts and Exits in Venture Capital Finance. Review of Financial Studies 21, 1947-1982.

Cumming D.J., 2015. Publishing in Finance versus Entrepreneurship/Management Journals. In Tim Clark, Dave Ketchen, and Mike Wright, eds., "How to Get Published in the Top Management Journals", forthcoming.

Cumming, D.J., Fleming, G., Suchard, J.A., 2005. Venture Capitalist Value Added Activities, Fundraising and Drawdowns. Journal of Banking and Finance 29, 295-331.

Cumming, D.J., and S.A. Johan, 2008a. Information Asymmetries, Agency Costs and Venture Capital Exit Outcomes. Venture Capital: An International Journal of Entrepreneurial Finance 10, 197-231.

Cumming, D.J., Johan, S.A., 2008b. Preplanned exit strategies in venture capital, European Economic Review 52, 1209-1241.

Cumming, D.J., Johan, S.A., 2013. Venture Capital and Private Equity Contracting: An International Perspective, 2nd Edition, Elsevier Science Academic Press.

Cumming, D.J., Schmidt, D., Walz, U., 2010. Legality and Venture Capital Governance around the World. Journal of Business Venturing 25, 54-72.

Cumming, D.J., Vismara S., 2016. A Research Journey into Entrepreneurial Finance. In "Companion to Makers of Modern Entrepreneurship". Edited by David B. Audretsch \& Erik E. Lehmann: Routledge.

Cumming, D.J., Walz, U., Werth, J.C., 2016. Entrepreneurial Spawning: Experience, Education, and the Role of Venture Capital. Financial Review. Forthcoming.

Cumming, D.J., Zambelli, S., 2016. Due diligence and investee performance, European Financial Management, forthcoming.

Cumming, D.J., Zhang, Y., 2016. Crowdfunding platforms, Working Paper, York University, Presented at EMLyon Venture Capital Conference July 2016.

Devigne D., Vanacker T., Manigart S. 2013. The role of domestic and cross-border venture capital investors in the growth of portfolio companies. Small Business Economics, 40(3): 553-573.

Hanssens, J., Deloof M., \& Vanacker, T., 2015. Underexplored issues in entrepreneurial finance. In D. B. Audretsch, C. S. Hayter, \& A. N. Link (Eds.), The Concise Guide to Entrepreneurship, Technology and Innovation. New York, NY: Edward Elgar.

Hanssens, J., Deloof M., \& Vanacker, T., 2016. The evolution of debt policies: new evidence from business startups. Journal of Banking and Finance 65, 120-133.

Hofstede, G., 1980. Culture's Consequences: International Differences in Work-Related Values. Beverly Hills, CA: Sage.

Judge W, Filatotchev I, Aguilera R, 2010. Comparative corporate governance and international business research. 18(6), 493-495. 
Judge, W. Q., Witt, M. A., Zattoni, A., Talaulicar, T., Chen, J. J., Lewellyn, K., Hu, H. W., Shukla, D., Bell, R. G., Gabrielsson, J., Lopez, F., Yamak, S., Fassin, Y., McCarthy, D., Rivas, J. L., Fainshmidt, S., Van Ees, H., 2015. Corporate governance and IPO underpricing in a cross-national sample: A multilevel knowledge-based view. Strategic Management Journal 36, 1174-1185.

Khurshed A., Paleari S., Pandè A., Vismara S., 2014. Transparent bookbuilding, certification and initial public offerings. Journal of Financial Markets, 19, 154-159.

La Porta, R., Lopez-de-Silanes, F., Shleifer, A., Vishny, R., 1998. Law and Finance. Journal of Political Economy 106, 1113-1155.

Leahy, Erin, 2007. Not by Productivity Alone: How Visibility and Specialization Contribute to Academic Earnings. American Sociological Review 72(4), 533-561

Lerner, J., Schoar, S., 2005. Does Legal Enforcement Affect Financial Transactions?: The Contractual Channel in Private Equity. Quarterly Journal of Economics, 120, pp. 223246.

Levis M., Vismara S. (eds), 2013. Handbook of Research on IPOs. Edward Elgar, Cheltenham.

Martin, B.R., 2013. Whither Research Integrity? Plagiarism, Self-plagiarism and Coercive Citation in an Age of Research Assessment. Research Policy, 42, 1005-1014.

Martin, B.R., 2016, 'Editors' JIF-boosting stratagems - Which are appropriate and which not?', Research Policy, 45, 1-7.

Meoli M., Paleari S., Vismara S., 2013. Completing the Technology Transfer process: M\&As of Science-Based IPOs. Small Business Economics, 40 (2), 227-248.

Migliorati K., Vismara S., 2014. Ranking Underwriters of European IPOs. European Financial Management, 20(5), 891-925.

Minola T., Vismara S., Hahn D., 2016. Screening model for the support of governmental venture capital. Journal of Technology Transfer, forthcoming.

Paleari S., Signori A., Vismara S., 2014. How do underwriters select peers when valuing IPOs? Financial Management, 43(4), 731-755.

Ritter, J., 2013. Re-energizing the IPO Market. 123-145, in "Restructuring to Speed Economic Recovery", edited by Martin Neil Bailey, Richard J. Herring, and Yuta Seki, Brookings Press.

Robb, A. M., Robinson, D. T., 2014. The Capital Structure Decisions of New Firms. Review of Financial Studies, 27(1): 153-179

Stiglitz, J.E. and Weiss, A., 1981. Credit Rationing in Markets with Imperfect Information. American Economic Review, 71 (3), 393-410.

Vanacker, T., Heughebaert, T., Manigart, S., 2014. Institutional frameworks, venture capital and the financing of European new technology-based firms. Corporate Governance: An International Review, 22(3), 199-215.

Vismara S., 2016a. Equity retention and Social Network Theory in Equity Crowdfunding. Small Business Economics, forthcoming.

Vismara S., 2016b. Information cascades among investors in equity crowdfunding. SSRN working paper.

Vismara S., Paleari S., Ritter J. R., 2012. Europe's Second Markets for Small Companies”, European Financial S., 18(3), 352-388.

Vismara S., Signori A., Paleari Stefano, 2015. Changes in underwriters' selection of comparable firms pre- and post-IPO: same bank, same company, different peers. Journal of Corporate Finance, 34, 235-250.

Wilson, K. and F. Silva. 2013. Policies for Seed and Early Finance: Findings from the 2012 OECD Financing Questionnaire. OECD Science, Technology and Industry Policy Papers, No. 9, OECD Publishing. http://dx.doi.org/10.1787/5k3xqsf00j33-en. 
Zattoni, A. and Judge, W. (eds.), 2012. Corporate Governance and Initial Public Offerings: An International Perspective, Cambridge University Press, Cambridge. 
Table 1. Means of financing for entrepreneurial firms.

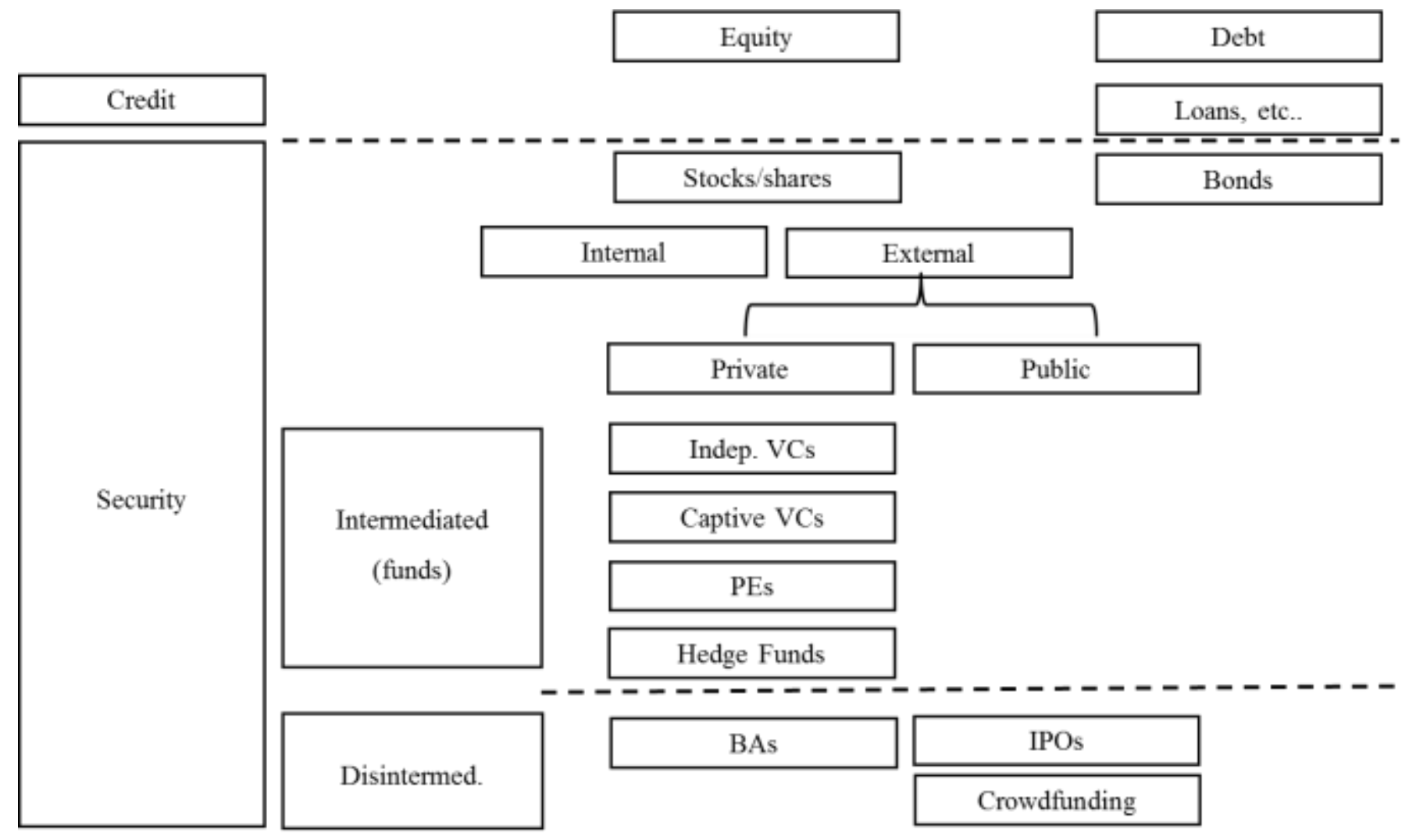

This table offers a taxonomy of means of financing for entrepreneurial firms, distinguishing between debt and private vs public equity, credit and securities markets, intermediate and disintermediates finance. We do not include all financing means (e.g. mezzanine financing, bootstrap financing, public subsidies) and classifications 